\title{
Microscopic investigation of changes in histology and digestibility in the rumen of a forage grass and a forage legume during the first growth stage
}

\author{
J Jamot *, E Grenet \\ Station de Recherches sur la Nutrition des Herbivores, INRA, Theix, 63122 Ceyrat, France
}

(Received 12 December 1990; accepted 29 March 1991)

\begin{abstract}
Summary - An Italian "Dalita" ryegrass (Lolium italicum) and a European lucerne (Medicago sativa) were harvested at 5 different growth stages to determine the anatomical factors limiting their digestibility and in particular the effects of lignification of the tissues. In vitro digestibility, cell wall contents of the whole plant and stem of lucerne and of the whole plant, stem and leaf blade of ryegrass were determined. The rate and the extent of degradation in the rumen of the different tissues were observed by scanning electron microscopy. This degradation occurred very rapidly with the lucerne stems; the xylem of lucerne was the only undegradable tissue whatever the stage. The collenchyma was degraded in the rumen although with acid phloroglucinol it stained positive for the presence of phenolic compounds. Ryegrass stems were digested more slowly than lucerne stems, and the sclerenchyma and xylem of ryegrass were indigestible whatever the stage. The parenchyma located close to the sclerenchyma became indigestible as the cell walls lignified progressively from the third stage. These results contribute to the understanding of the decrease in digestibility over the first growth stage and the variation in rate of digestion of lucerne and ryegrass in the rumen.
\end{abstract}

grass/ legume / digestibility / lignification / microscopy

Résumé - Étude microscopique de l'évolution de la structure histologique et de la dégradation dans le rumen d'une graminée et d'une légumineuse au cours du premler cycle de végétation. Un ray-grass d'ltalie "Dalita" (Lolium italicum) et une luzerne Europe (Medicago sativa) récoltés à 5 stades de maturité différents ont été étudiés pour déterminer les facteurs histologiques limitant leur digestibilité notamment le degré de lignification des tissus. La digestibilité in vitro et les teneurs en parois ont été mesurées sur la plante entière et la tige de luzerne, la plante entière, la tige et le limbe du ray-grass. La vitesse et l'importance de la dégradation des différents tissus dans le rumen ont été étudiés au microscope électronique à balayage. Cette dégradation est très rapide pour les tiges de luzerne, dont le xylème est le seul tissu indigestible quel que soit le stade considéré. Le collenchyme est digéré dans le rumen bien qu'il montre une réaction positive à la phloroglucine chlorhydrique. Dans les tiges de ray-grass, qui sont dégradées plus lentement que les tiges de luzerne, le sclérenchyme et le xylème sont indigestibles quel que soit le stade; à partir du $3^{\circ}$ stade le parenchyme, situé sous le sclérenchyme, devient également indigestible car ses parois se sont pro-

\footnotetext{
* Correspondence and reprints
} 
gressivement lignifiées. Ces résultats contribuent à expliquer la diminution de la digestibilité observée avec l'áge de la plante, et les différences de vitesse de dégradation dans le rumen de la luzerne et du ray-grass.

graminée / légumineuse / digestiblité / lignification / microscopie

\section{INTRODUCTION}

The morphological and chemical characteristics of a plant and thus its digestibility depend on the species, growth cycle, growth stage and environment. Digestibility is highest during the initial growth phase, but is highly related to the stage of development of the plant. Voluntary intake and digestibility of a forage decrease with maturity. However, with similar digestibilities, legumes are ingested in larger amounts than grasses (Van Soest, 1965), the difference increasing with the growth stage. Both parameters, voluntary intake and digestibility, depend on the morphological and chemical composition of plants (Hacker and Minson, 1981). In the initial growth phase the proportion of leaf blades is at a maximum and then decreases rapidly as the proportion of stems increases. This proportion is less variable in legumes because stems are present from the beginning of the growth cycle (Demarquilly and Andrieu, 1988).

The anatomy of plants and the proportion of the different tissues influence forage digestion in the rumen (Akin, 1979). As the digestibility of cell contents is total or very high, forage digestibility is limited by cell wall digestiblity which may range between $90 \%$ for young ryegrass and $40 \%$ for cereal straws. For the same cell wall content, legumes, which have a high content of cell solubles, are more rapidly digested in vivo than grasses (Jarrige, 1981).

An increase in cell wall content occurs in parallel with a change in cell wall com- position with increasing maturity, especially during the initial growth phase. Lignin content increases in cell walls and influences the rate and extent of polysaccharide degradation by rumen microorganisms (Barton and Akin, 1977; Grenet and Demarquilly, 1987). This increase is larger in stems than in leaves, particularly as regards legumes. In the legumes, cell walls of leaf blades have a relatively stable composition. The plant polysaccharides of supporting and conducting tissues are encrusted with lignin (Jarrige, 1963). It increases their rigidity and prevents attack by microorganisms. The lignin-carbohydrate complexes (Chesson, 1988) are not degraded (Jung and Fahey, 1983). They constitute the indigestible cell wall and the content as a proportion of dry matter increases with maturity.

In order to understand the change with maturity in grass and legume digestibility, it is necessary to distinguish between the 2 mechanisms involved: the formation of tissues with an increased cell wall content and different composition; and on the other hand, the lignification of tissues which renders them indigestible (Jarrige, 1963). This investigation has not been carried out until now. The objective of this work was to study the variations in cell wall composition and in vitro digestibility in samples of leaves, stems and whole plants of one Italian ryegrass and one lucerne harvested at 5 growth stages over the first growth cycle. Light microscopy (LM) and scanning electron microscopy (SEM) were used to examine the changes in anatomy and ultrastructure and the rate of degradation of the different tissues in the rumen. 


\section{MATERIALS AND METHODS}

\section{Sample collection and storage}

An Italian "Dalita" ryegrass (Lolium italicum) and a Europe lucerne (Medicago sativa) were harvested at 5 different growth stages during the first growth cycle (table I).

One hundred samples from whole plants of both species, the fifth internode from the bottom for lucerne, the third for ryegrass as well as the corresponding leaf blade were selected at each stage of maturity. Leaf blades of ryegrass were not harvested at the last stage because they were dried off. Leaves of lucerne were not harvested as they do not contain lignified tissues except the xylem of leaf veins and thus are very rapidly digested in the rumen.

Samples were dried at $60^{\circ} \mathrm{C}$ for $48 \mathrm{~h}$ before cell wall content and in vitro digestibility determination. They were ground (mesh size $0.8 \mathrm{~mm}$ ). For microscopic examination, $0.5-\mathrm{cm}$ stem samples were removed from the center of the internode. Samples of the leaf $(0.5 \mathrm{~cm}$ by $t \mathrm{~cm})$ were removed from the center of the leaf blade. Samples were frozen and stored at $-15^{\circ} \mathrm{C}$ until used.

\section{Cell wall content and in vitro digestibility}

Cell wall content was determined according to the method of Goering and Van Soest (1970) as neutral detergent fiber (NDF). In addition, acid detergent fiber (ADF) and acid detergent lignin (ADL) were determined. Dry matter digestibility was determined in vitro using the pepsincellulase technique (Aufrère, 1982).

\section{Kinetics of microbial degradation in the rumen}

For ultrastructural study of degradation by rumen bacteria, 6 samples of stems for lucerne, and 6 samples of stems and blades for ryegrass were put into nylon bags (Demarquilly and Chenost, 1969). For the 5 growth stages, the different substrates remained $8,24,48$ and $72 \mathrm{~h}$ in the rumen of a cannulated (75 $\mathrm{mm}$ diameter) sheep fed lucerne hay. Nylon bags were introduced into the rumen before a meal.

\section{Microscopic examination}

\section{Light microscopy}

Free-hand sections were taken from the control samples (table I) and stained with acid phloroglucinol for light microscopic identification of cell walls rich in coniferaldehyde units. The Maüle reaction was used to identify lignified tissues with a high syringylpropane unit content (Langeron, 1949; Vance et al, 1980).

Table I. Samples harvested during the 1st cycle.

\begin{tabular}{|c|c|c|c|c|}
\hline Harvest & & Date & Ryegrass stage & Lucerne stage \\
\hline 1 & (very early) & 18 May & Stem elongation & Vegetative \\
\hline 2 & & 2 June & & \\
\hline 3 & & 14 June & Heading & Bud formation \\
\hline 4 & & 28 June & & Early bloom \\
\hline 5 & (late) & $\begin{array}{l}7 \text { July } \\
4 \text { August }\end{array}$ & & $\begin{array}{l}\text { Full-bloom } \\
\text { "straw" }\end{array}$ \\
\hline
\end{tabular}




\section{Scanning electron microscopy (SEM)}

Control samples of both species and samples digested in the rumen (the latter were rinsed with water after digestion) were prepared for SEM using the method described by Grenet and Barry (1988) with the following modifications: substrates were fixed for $24 \mathrm{~h}$ (instead of $3 \mathrm{~h}$ ) at room temperature in a $4 \%$ (V/V) glutaraldehyde solution in a sodium cacodylate buffer $(0.2 \mathrm{M}$ at $\mathrm{pH} 7.4)$.

\section{RESULTS}

\section{Chemical composition and in vitro digestibility}

In both species, the increase with age in dry matter (DM) of the whole plant was similar. It varied from $12-22 \%$ and $13-$ $27 \%$ respectively for lucerne and ryegrass between the first and the last stage of maturity (table II).

In ryegrass, the cell wall content in the different plant parts did not vary in the same proportions between the harvests (table II). In the whole plant, the NDF content varied from $50-62 \%$, and that of ADF from $30-38 \%$. In the internodes, these contents were almost equal (NDF: 57 to $59 \%$, ADF: $36-38 \%$ ). By contrast, in lucerne the NDF, ADF and lignin contents varied similarly in the whole plant and in the internodes. The whole plant of lucerne had a lower NDF content (39-56\%), but a higher ADF (29-43\%) and lignin (6-10\%) content than ryegrass, the amount of differences between species depending on the growth stage.

Digestibility of both species was similar for the whole plant (table II). It decreased with maturity together with an increase in the cell wall content. Digestibility of lucerne decreased from 72.8 to $55.3 \%$ for the whole plant between harvests 1 and 5 and from 61.9 to $41.0 \%$ for the internodes. Likewise, digestibility of ryegrass decreased from 75.8 to $53.3 \%$ for the whole plant and from 66.8 to $50.3 \%$ for the internodes. Thus, the digestibility of ryegrass internodes was 5 points higher than that of the lucerne internodes. Digestibility of ryegrass blades was high and little affected by harvest (from 80 to $77 \%$ ).

\section{Observations with light microscopy}

The development of lignified tissues in lucerne and ryegrass stems over the 5 harvests was shown by light microscopy after staining with acid phloroglucinol and Maüle reagent (table III). Lignification of lucerne internodes changed little between stages 1 and 5. Lignified tissues, indicated by a positive acid phloroglucinol and Maüle reaction, were found in the xylem cells from the first stage of maturity. The external part of the collenchyma stained positive (pink) with the lignin reagents.

In ryegrass stems, sclerenchyma ring stained positive with acid phloroglucinol and Maüle reagent from the first stage of maturity. A strong staining occurred in the sclerenchyma from harvest 4 . The fibres of the vascular bundles and xylem cells were also lignified from harvest 1 . Lignin appeared gradually in the parenchyma from the outer area close to the sclerenchyma to the medullary area; no reaction was observed whatever the stage in the inner area of the parenchyma.

The sclerenchyma and xylem of leaf veins in ryegrass blades were stained by acid phloroglucinol from the first stage. This reaction was more pronounced in the midvein. The Maüle reaction was poorly positive in the xylem of vascular bundles.

In all our observations staining was always less pronounced with Maüle reagent than with acid phloroglucinol. 


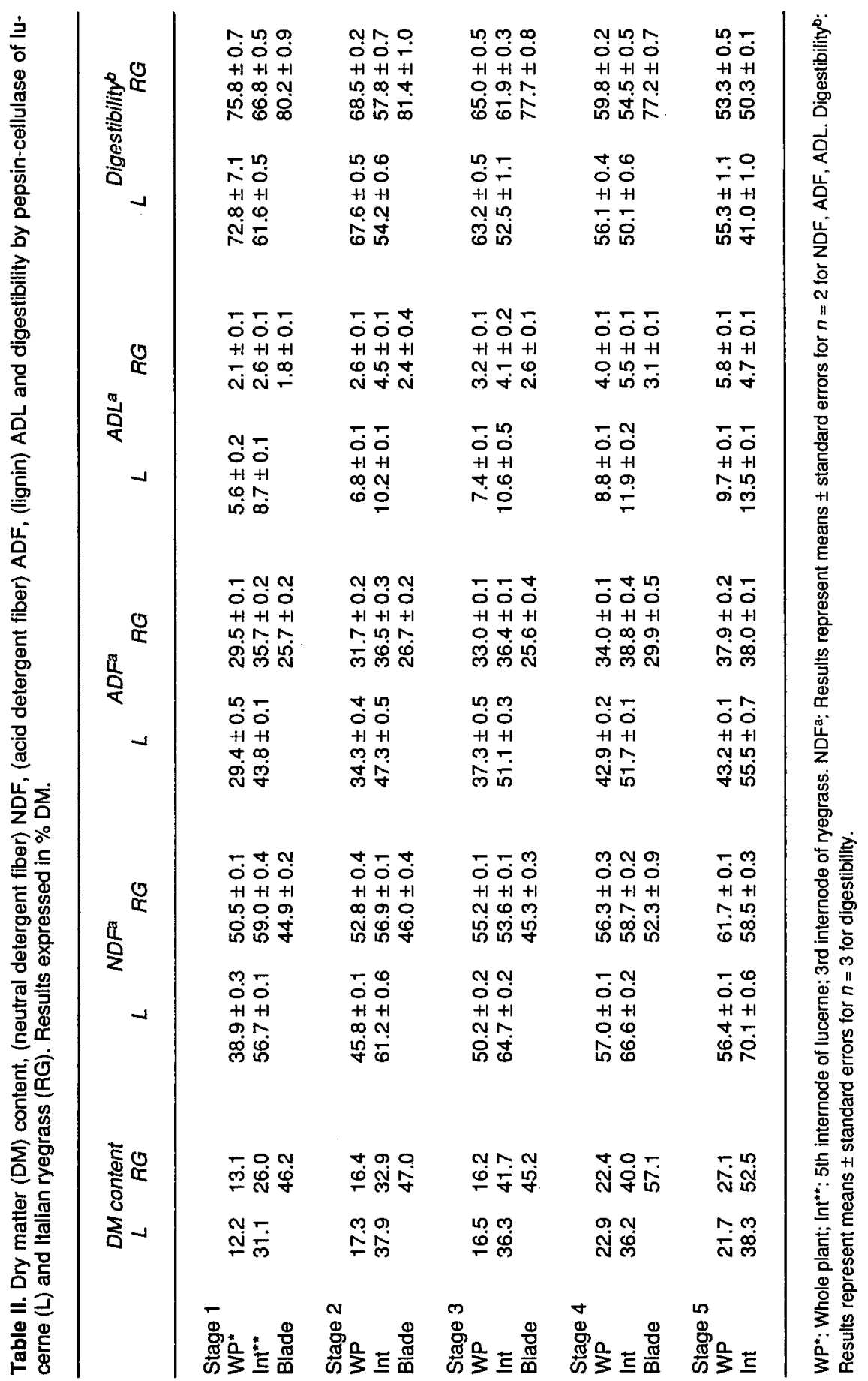


Table III. Lignification score of stem tissues stained positive with acid phloroglucinol ( $P$ ) and (or) Maüle $(M)$ reaction.

\begin{tabular}{|c|c|c|c|c|c|c|c|c|c|c|}
\hline \multirow[t]{2}{*}{ Harvest } & \multicolumn{2}{|c|}{ Epidermis } & \multicolumn{2}{|c|}{ Collenchyma } & \multicolumn{2}{|c|}{ Sclerenchyma } & \multicolumn{2}{|c|}{ Xylem } & \multicolumn{2}{|c|}{ Parenchyma } \\
\hline & $P$ & $M$ & $P$ & $M$ & $P$ & $\dot{M}$ & $P$ & $M$ & $P$ & $M$ \\
\hline \multicolumn{11}{|l|}{ Int ${ }^{* *}$ lucerne } \\
\hline Stage 1 & & & 2 & 2 & & & 3 & 2 & & \\
\hline 2 & & & 2 & 1 & & & 3 & 3 & & \\
\hline 3 & & & 2 & 1 & & & 3 & 3 & & \\
\hline 4 & & & 2 & 1 & & & 3 & 2 & & \\
\hline 5 & & & 3 & 2 & & & 3 & 3 & & \\
\hline \multicolumn{11}{|l|}{ Int ryegrass } \\
\hline Stage 1 & 1 & 1 & & & 2 & 1 & 2 & 1 & & \\
\hline 2 & 2 & 1 & & & 2 & 1 & 3 & 2 & & \\
\hline 3 & 2 & 1 & & & 2 & 1 & 3 & 2 & 1 & 1 \\
\hline 4 & 3 & 2 & & & 3 & 2 & 3 & 2 & 3 & 2 \\
\hline 5 & 3 & 2 & & & 3 & 2 & 3 & 2 & 3 & 2 \\
\hline \multicolumn{11}{|c|}{ Ryegrass blade } \\
\hline Stage 1 & & & & & 2 & 1 & 2 & 1 & & \\
\hline 2 & & & & & 2 & 1 & 2 & 1 & & \\
\hline 3 & & & & & 2 & 1 & 2 & 1 & & \\
\hline 4 & & & & & 3 & 2 & 3 & 2 & & \\
\hline
\end{tabular}

* 1 = weakly stained; $2=$ stained; $3=$ heavily stained. $I n^{* *}=$ internode.

\section{Observations \\ with scanning electron microscopy}

\section{Controls}

The structure of lucerne internodes changed gradually with maturity as shown by microscopic examination. The area of medullary parenchyma decreased as the pith cavity widened and lignified tissues (xylem) increased (figs 1,2). Sclerenchy$\mathrm{ma}$, the supporting lignified tissue of ryegrass stems, did not change in thickness between stage 1 and stage 4 (figs 3,4 ). The structure of blades changed little over the 1 st cycle (fig 5).

\section{Kinetics of degradation in the rumen}

The degree of microbial degradation of the lucerne stem depended on the age and on the tissue. After $8 \mathrm{~h}$ in the rumen, phloem was absent whatever the stage, whereas parenchyma and collenchyma were partially degraded (fig 6). Epidermis was separated and often torn away. Degradation of non-lignified tissues (parenchyma and phloem) was total after $24 \mathrm{~h}$ in samples from the first 4 harvests (fig 7). Some medullary parenchyma remained in the samples of stage 5 after $72 \mathrm{~h}$ digestion in the rumen.

Microbial degradation of the ryegrass stem harvested at the first stage was total 

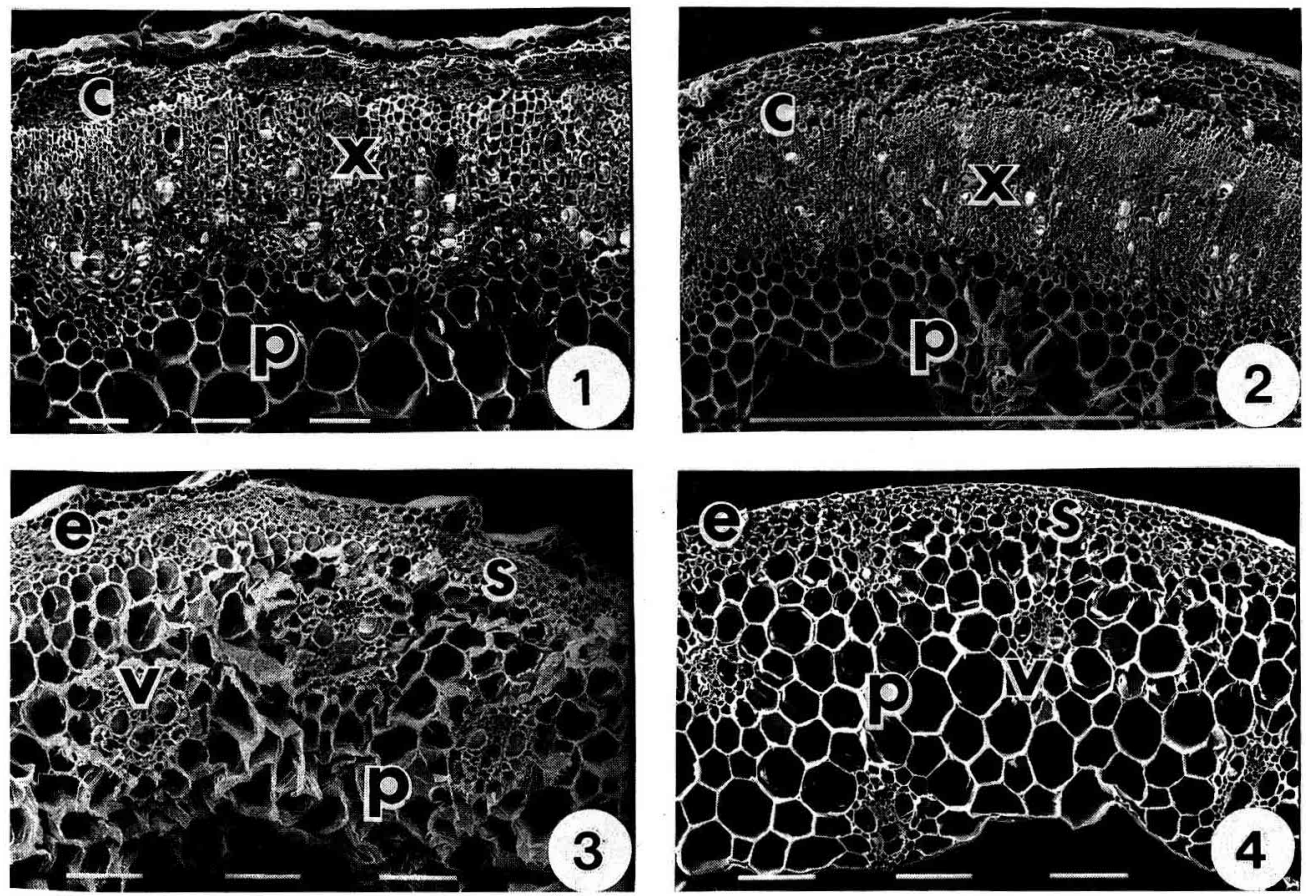

Figs 1-4. 1. Cross-section of the 5th internode of lucerne harvested at stage 1 shown by SEM. C = collenchyma; $P=$ parenchyma; $X=x y l e m$. Bar $=0.1 \mathrm{~mm}$. 2. Cross-section of the 5 th internode of lucerne harvested at stage 5 shown by SEM. $C=$ collenchyma; $P=$ parenchyma; $X=x y l e m$. Bar $=1$ $\mathrm{mm}$. 3. Cross-section of the 3rd internode of ryegrass harvested at stage 1 shown by SEM. $E=$ epidermis; $P=$ parenchyma; $S=$ sclerenchyma; $V=$ vascular bundles. Bar $=0.1 \mathrm{~mm}$. 4. Cross-section of the 3rd internode of ryegrass harvested at stage 4 shown by SEM. $E=$ epidermis; $P=$ parenchyma; $S$ = sclerenchyma; $V=$ vascular bundles. $B a r=0.1 \mathrm{~mm}$.

for all non-lignified tissues (parenchyma and phloem) after 8-h digestion in the rumen. It was almost total after 24-h digestion for stages 2 and 3 (fig 8) and after $48 \mathrm{~h}$ for the last 2 stages. The cuticle was intact even after $72 \mathrm{~h}$ digestion in the rumen (fig 9).

Microscopic examination of ryegrass blades was performed after only $8 \mathrm{~h}$ digestion in the rumen (fig 10). After this time, samples of blades were too damaged. Degradation of mesophyll, phloem and epidermis was total whatever the age. Cuticle and lignified tissues, xylem and parenchyma, were intact (fig 10).

Microscopic examination of stem sections from both species showed colonization of tissues by rumen fungi mainly after 24 h (fig 7). 

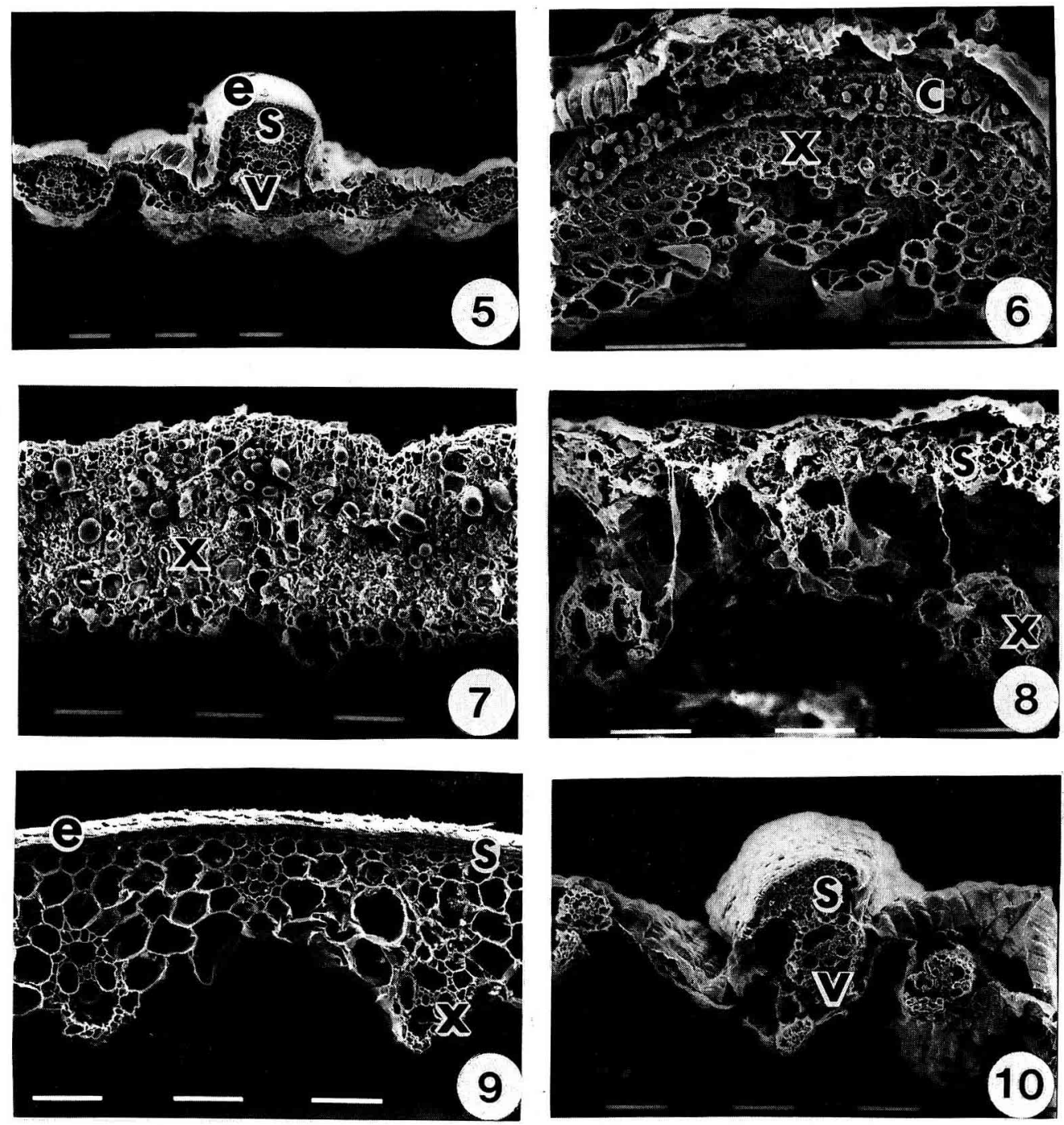

Figs 5-10. 1. Cross-section of a blade of ryegrass harvested at stage 4 shown by SEM. $E=$ Epidermis; $S=$ sclerenchyma; $V=$ vascular bundles. $B a r=0.1 \mathrm{~mm}$. 6. Cross-section of the 5 th internode of lucerne harvested at stage 1 after $8 \mathrm{hr}$ digestion in the rumen shown by SEM. Phloem is totally degraded; parenchyma $(P)$ and collenchyma $(C)$ are being degraded. Xylem $(X)$ is undegraded. Bar $=0.1$ $\mathrm{mm}$. 7. Cross-section of the 5th internode of lucerne, harvested at stage 4 and digested $24 \mathrm{hr}$ in the rumen, shown by SEM. Xylem (X), highly colonized by the rumen fungi is intact. Bar $=0.1 \mathrm{~mm}$. 8 . Cross-section of the 3rd internode of ryegrass, harvested at stage 2 and digested $24 \mathrm{~h}$ in the rumen, shown by SEM. Parenchyma and phloem are degraded. Bar $=0.1 \mathrm{~mm}$. 9. Cross-section of the 3rd internode of ryegrass, harvested at stage 2 and digested $24 \mathrm{~h}$ in the rumen, shown by SEM. Parenchy$\mathrm{ma}$ and phloem are degraded. Bar $=0,1 \mathrm{~mm}$. 9. Cross-section of the 3rd internode of ryegrass, harvested at stage 5 and digested $72 \mathrm{~h}$ in the rumen. Epidermis $(E)$, sclerenchyma $(S), x y l e m(X)$ and lignified parenchyma are intact as shown by SEM. Bar $=0.1 \mathrm{~mm}$. 10 . Cross-section of a blade of ryegrass, harvested at stage 4 and digested $8 \mathrm{~h}$ in the rumen, shown by SEM. The xylem of vascular bundles $(V)$ and sclerenchyma $(S)$ are not degraded. $B a r=0.1 \mathrm{~mm}$. 


\section{DISCUSSION}

Anatomical differences contribute to the variation in ryegrass and lucerne digestibility over the first growth stage as affected by changes in the shemical composition. Digestibility of the whole plant mainly depends on the internocle digestibility, as that of leaves changes little (decrease by 5 points over the 1st cycle for grass blades). Differences in digestibility related to maturity are more marked (decrease by 20 points) than those related to the plant species (maximum 5 points at the same age). These results are consistent with those obtained in clover by Akin and Robinson (1982).

The ryegrass and lucerne tissues are degraded in the rumen if their cell walls are not lignified, but their rate of degradation is variable. The different tissues found intact after rumen digestion, ie, xylem, sclerenchyma and even parenchyma in the older ryegrass, can be identified by positive staining with acid phloroglucinol. Modifications observed in the reaction of the tissues to acid phloroglucinol and Maüle reactant as affected by plant maturity show some evidence of a qualitative evolution of lignin (methoxylation) particularly concerning the sclerenchyma of ryegrass. However, there is not necessarily a quantitative relationship between the intensity of staining and the lignin contents of the cell walls (Czaninski et al, 1990). Lignification of part of the parenchyma was also observed by Akin and Burdick (1981) in Cynodon dactyIon and by Barry and Grenet (1988) in wheat. Contrary to the observations of Akin and Robinson (1982) in the clover stem, we did not detect any lignification of the parenchyma in the lucerne stem. However, in the latter, a positive staining of the collenchyma with acid phloroglucinol was observed at each maturity, whereas this tissue is degraded in the rumen. According to Hartley (1982), the acid phloroglucinol reaction may be positive with lignin monomers, particularly the aromatic aldehydes and their methyl esters present in the cell walls of forage grass (Hartley and Keene, 1983). The reaction of the collenchyma in the lucerne stem might be explained by the presence of these compounds. It is therefore advisable to use this test with caution to estimate the degradability of tissues in the rumen (Hartley, 1982; Engels, 1989).

For a similar digestibility, the rate of degradation of ryegrass and lucerne tissues in the rumen is variable (Grenet and Jamot, 1989). In lucerne stem, whatever the stage, all the tissues, except xylem, are totally degraded after $24 \mathrm{~h}$ in the rumen, as already observed by Brazle and Harbers (1977) in lucerne hay. By contrast, the ryegrass stem is less degraded after the same period of time. Part of the parenchyma is intact. Except for the lignified cells, it is totally degraded after $48 \mathrm{~h}$ digestion. These differences partly explain why lucerne is better ingested than ryegrass at similar digestibility. Moreover, it has been established (Grenet and Demarquilly, 1987) that lucerne has a higher cell content, which is more rapidly and totally digested in the rumen. As a result, lucerne particles leave the rumen more rapidly so that the animals have a higher feed intake.

Microscopic examinations show that, for a similar digestibility, lucerne is more rapidly degraded in the rumen than ryegrass because of its anatomical characteristics. This may explain its higher voluntary intake. However, the mechanisms preventing the degradation of polysaccharides present in the lignified cell walls of forages are still unknown, and in particular the part played by the lignin-carbohydrate complexes. 


\section{REFERENCES}

Akin DE (1979) Microscopic evaluation of forage digestion by microorganisms - a review. $J$ Anim Sci 48, 701-710

Akin DE, Burdick D (1981) Relationships of different histochemical types of lignified cell walls to forage digestibility. Crop Sci 21,577 581

Akin DE, Robinson EL (1982) Structure of leaves and stems of arrowleaf and crimson clovers as related to in vitro digestibility. Crop Sci 22, 24-29

Aufrère $J$ (1982) Étude de la prévision de la digestibilité des fourrages par une méthode enzymatique. Ann Zootech 31, 111-130

Barry P, Grenet E (1988) Dégradation microbienne dans le rumen de la tige de blé à différents stades de développement, observée au microscope électronique à balayage. $R e-$ prod Nutr Dév 28 suppl 89-90

Barton FE, Akin DE (1977) Digestibility of delignified forage cell walls. $J$ Agric Food Chem $25,1299-1304$

Brazle FK, Harbers LH (1977) Digestion of alfafa hay observed by scanning electron microscopy. J Anim Sci 46, 506-512

Chesson A (1988) Lignin-polysaccharide complexes of the plant cell wall and their effect on microbial degradation in the rumen. Anim Feed Sci Tech 21, 219-228

Czaninski Y, Monties B, Grech I (1990) Quelques méthodes cytochimiques d'étude de la lignification. Sém Lignine, Nancy (France) 15-16 Oct 1990, p 12

Demarquilly C, Chenost M (1969) Etude de la digestion des fourrages dans le rumen par la méthode des sachets de nylon; liaisons avec la valeur alimentaire. Ann Zootech 18, 419436

Demarquilly C, Andrieu J (1988) Les fourrages. In: Alimentation des Bovins, Ovins et Caprins. INRA Publ, 315-335

Engels FM (1989) Some properties of cell wall layers determining ruminant digestion. In: Physico-Chemical Characterization of Plant Residues for Industrial and Feed Use (Ches- son A, Orskov ER, eds) Elsevier, Amsterdam, 80-87

Goering HK, Van Soest PJ (1970) Forage fiber analyses. In: Agric Handbook 379. US Department of Agriculture, Washington DC

Grenet $E_{1}$ Demarquilly C (1987) Digestion des fourrages dans le rumen. In: Les Fourrages Secs: Récolte, Traitement, Utilisation (Demarquilly C, ed) INRA, 141-162

Grenet E, Barry P (1988) Colonization of thickwalled plant tissues by anaerobic fungi. Anim Feed Sci Technol 19, 25-31

Grenet E, Jamot J (1989) Kinetic study of the rumen microbial degradation of lucerne and Italian ryegrass observed by scanning electron microscopy. 16th Int Grassland Congr, Nice, France, 1989

Hacker JB, Minson DJ (1981) The digestibility of plant parts. Herb Abstr 51, 459-482

Hartley RD (1982) Non-carbohydrate constituents and properties of plant cell wall in relation to its digestion. In: Fibre in Human and Animal Nutrition. R Soc New Zealand, Wellington, New Zealand, 81-84

Hartley RD, Keene S (1983) Aromatic aldehyde constituents of graminaceous cell walls. Phytochemistry 23 (Oxf) 23 (1984), 1305-1307

Jarrige $R$ (1963) Les constituants membranaires des plantes fourragères. Ann Biol Anim Biochim Biophys 3, 143-190

Jarrige R (1981) Les constituants glucidiques des fourrages : variations, digestibilité et dosage. In : Prévision de la Valeur Nutritive des Aliments des Ruminants. INRA Publ, Versailles

Jung HG, Fahey GC (1983) Nutritional implications of phenolic nonomers and lignin: a review. J Anim Sci 57, 1983

Langeron M (1949) Précis de Microscopie. Masson, Paris

Vance CP, Kirk TK, Sherwood RT (1980) Lignification as a mechanism of disease resistance. Annu Rev Phyto-pathol 18, 259-288

Van Soest PJ (1965) Symposium on factors influencing the voluntary intake of herbage by ruminants: voluntary intake in relation to chemical composition and digestibility. J Anim Sci 834-845 